371.3::811.163.41'243

811.163.41'373.7

https://doi.org/10.18485/msc_saopstenja.2018.48.1.ch6

Светлана В. ГОљАК*

Универзитет у Београду

Филолошки факултет
Оригинални научни рад

Примљен: 02. 12.2018 .

Прихваћен: 03. 12. 2018.

\title{
МЕТОДИЧКИ АСПЕКТИ НАСТАВЕ ФРАЗЕОЛОГИЈЕ СРПСКОГ ЈЕЗИКА КАО СТРАНОГ
}

\footnotetext{
У раду се на основу резултата савремених истраживања фразеологије примењених у методици наставе врши поређење фразеологизама српског и других језика, истиче се методолошки значај примене појма „модел” у анализи устаљених израза, што се илуструје на примеру фразеологизама са значењем безумља, значењем 'никад', као и израза мотивисаних сликама како из сфере музике, тако и других.
}

Кључне речи: фразеологизам, српски језик, методика наставе, модел.

1. Називајући језик једног народа „сликом спољњег света, одраженом у његовој свести", Александар Белић указује на различит садржај којим су испуњене речи у различитим језицима (Белић 1951: 14). Фразеологизми, као устаљени вишелексемни спојеви, који се репродукују из генерације у генерацију, представљају јединице од посебног значаја за откривање важних елемената слике света, коју језик и одражава, и формира. Они постају „повољна „спремишта” за најразличитије културне садржаје” (Мршевић Радовић 2008: VI). Фразеологизми су у тесној вези са националном традицијом, обичајима и веровањима, историјским догађајима, са народном етиком и филозофијом.

Проналажење веза између језика и културе, тумачење културног садржаја фразеологизама, предмет је лингвокултуролошких, етнолингвистичких и других истраживања фразеологије која припадају антрополошкој научној парадигми. Резултати савремених истраживања се могу успешно примењивати у методици наставе фразеологије. Разумевање елемената језичке слике света који се садрже у семантици фразеологизама свакако доприноси дубљем разумевању и бољем усвајању устаљених израза како матерњег тако и страног језика.

*svetlanagoljak@yahoo.co.uk 
У овом раду ћемо показати примену појма „модел” у методици наставе фразеологије српског језика као страног, базирајући се на истраживањима националног и интернационалног у фразеологији, односно истраживањима заједничких елемената и разлика између сличних група израза у неколико језика.

Појам „модел” такође разматрамо у контексту колективне свести и језичке слике света, следећи став Д. Мршевић-Радовић: „Разматрајући фразеолошку семантику настојали смо да утврдимо да ли посматране фразеолошке јединице одражавају моделе значења који постоје у колективном језичком осећању говорника српског језика. Кад год је то фразеолошки материјал омогућавао, вршена су упоређења са ситуацијом у другим словенским језицима да би се утврдило евентуално постојање заједничких/истоврсних језичких образаца за изражавање одређених погледа на свет” (Мршевић Радовић 2008: VIII).

2. Поређење фразеологизама различитих језика открива да устаљени изрази имају више заједничких особина него специфичних, а пре свега се уочавају заједнички модели њихове сликовите организације.

Појам „модел” у анализи фразеолошког значења примењује се на два нивоа: први је семантички, односно структурно-семантички ниво, када се анализирају везе између дословног и преносног значења израза (нпр. метафоре), док се на другом, макросемантичком нивоу истражују корелације између семиотичких кодова, културних система (тзв. макрометафоре).

2.1. У структурно-семантичким истраживањима фразеологије и паремиологије се активно користи појам „модел”. В. Мокијенко подразумева под њим „инваријант устаљених синтагми који семантички одражава релативну стабилност форме и значења" (Мокијенко 1989: 53). Тако, одређена група израза може да има релативно стабилне синтаксичке односе, као и слично значење. Као илустрација, могу да послуже фразеологизми који су на структурном плану зависне временске реченице са везником кад и који изражавају појам „никад”, односно значење „што се не може десити”. Примери су преузети из рада Ј. Солодуба (Солодуб 1982: 84) и допуњени изразима из словенских језика. Студентима је био предложен задатак да пронађу по чему су слични следећи изрази са значењем 'никад': срп. кад на врби роди грожђе; срп. дијал. кад гавран побели, кад рибе проговоре; рус. когда рак на горе свистнет (дословно „кад рак на брду зазвижди”); бел. дијал. як сарока бела стане (досл. „када сврака буде бела”); бел. заўтра ў тую пару, калі рак паляüius з вады ўгару (досл. „сутра када рак полети из воде); нем. wenn die Hunde mit dem Schwanz bellen (досл. „када пси почну да лају реповима”); енгл. when pigs fly (досл. „кад свиње полете”); франц. quand les poules auront des dents (досл. „када кокошке буду имале зубе”); узбекист. туянинг думи ерга текканда (досл. „када камилин реп буде до земље”). На основу анализе израза, формулисан је заједнички модел „када животиња / биљка буду имале немогуће својство које је у супротности са њиховом природом” = „никад”.

Проширивање овог модела би укључило у грађу и друге „алогичне” изразе: срп. дијал. кад се река врати уз Јелењак, рус. дијал. когда Волга вверх nотечет (примери из књиге: Мршевић Радовић 2008: 60-69). 
Даља анализа израза могла би да иде логиком „од заједничког према специфичном”, тј. од сличности ка разликама: неопходно је прокоментарисати зашто је у фразеологизму одређеног језика присутна конкретна биљка, животиња или друга појава, као и њено „необично” својство, тј. коју симболику она има (нпр. бели гавран у старој митологији итд.). Важан културни садржај (културни слој) српских „алогичних” израза са значењем 'никад', њихову повезаност са катаклизматичким и другим митовима показује Д. Мршевић-Радовић (Мршевић Радовић 2008: 60-69).

2.2. Фразеологизми такође могу да садрже исте базне метафоре, у смислу Џ. Лејкофа и М. Џонсона, и с тим у вези многи аутори говоре о истим когнитивним, односно концептуалним моделима у фразеологији, док се у лингвокултуролошкој школи користи термин „макрометафорички концептуални модел” (И. Зикова). Овде говоримо о повезаности два културна кода, два семиотичка система када се један изражава, објашњава кроз други.

Како би се илустровао овај аспекат анализе, студентима је био предложен задатак да пронађу сличности у сликовитој организацији низа израза из различитих језика, који имају како слично, тако и различито значење. Примери су преузети из чланка И. Зикове (Зикова 2014) и допуњени српским речима и изразима: срп. трубити (о нечему), рус. в трубу трубить (досл. „трубити трубу”) 'ширити гласине, вести'; срп. Засвирај - за појас задени 'треба знати када говорити, а када ћутати'; енгл. to face the music 'прихватати критику због нечег'; енгл. without missing a beat 'настављати говорити о нечему са сигурношћу'; рус. крутить шарманку и рус. заводить пластинку (досл. „свирати вергл”, „вртети плочу”) 'стално понављати једно те исто'.

У свим овим примерима уочавамо да се вербална комуникација описује кроз музичке појмове, односно да је овде представљен следећи „макрометафорички концептуални модел”: „Вербална комуникација је извођење музике" (Зыкова 2014: 365).

У фразеологији проналазимо корелације између различитих семиотичких система и њихових знакова, односно између „културних кодова” као што су музички код, биљни, зоолошки, предметни, митолошки, антрополошки итд. Слични модели у фразеологији различитих језика указују пре свега на сличан асоцијативан начин размишљања људи, слична знања о спољном свету. Овде се наглашава важна спона сликовитости и знања, односно начина размишљања, начина перцепције света, на шта указује и Ј. Караулов: „Извори језичке сликовитости су у систему знања" (Караулов 1987: 176). Ова идеја је још наглашенија у речима Е. Сепира: „Унутрашњи садржај свих језика је исти, а то је интуитивно поимање искуства. Само је њихов спољни облик бескрајно разнолик" (Сепир 1993: 193).

Са друге стране, на семантичком нивоу су присутне међујезичке разлике. Тако, горе наведен руски израз крутить шарманку („свирати вергл”) значи 'досадно, стално понављати једно те исто', што се базира пре свега на перцепцији понављања једноличног звука вергла и саме могућности механичке репродукције истог. Са друге стране, у српском језику је акценат на непрекидном окретању ручице вергла, због чега српски глагол верглати има 
скоро супротно значење 'говорити брзо, обично без размишљања': нпр. Верглао он [представљајући нас] као грамофон. Мотив окретања у контексту једноличног понављања присутан је у употреби глагола вртети у разговорном језику: срп. врти своју причу без престанка, опет вртии исто.

3. Применићемо појам „модел” у анализи речи и израза који означавају безумље, лудило, ментални поремећај, односно луду, ненормалну особу и неадекватно понашање у друштву. Грађа у српском и другим језицима је изузетно занимљива, жива, сочна, посебно ако се узму у обзир и дијалекти, жаргон. Ова грађа се детаљније обрађује у нашем раду (Гољак 2017), а овде ће нам одређени изрази послужити као илустрација примене појма „модел” у фразеологији.

У оквиру ове теме се издваја неколико фразеолошких модела, или идеја, мотива, сижеа око којих се групише највећи број израза. Њиховом анализом откривамо какво је народно тумачење узрока безумља, неадекватног понашања једне особе, и уопште како се замишљају и језичким средствима описују такве појава као што је разум, памет и здравље. Кратко ћемо размотрити три главна модела од издвојених седам.

3.1. Безумље као потпун губитак разума или његова „непотпуност”.

Разум је, ван сваке сумње, најзначајнији за ментално здравље, зато се стање особе која се понаша чудно, неконтролисано, повезује са губитком разума или његовом такозваном „непотпуношћу”, односно кад га нема довољно: без-ум-ан, без-ум-ље; изгубити памет 'полудети' (исти израз се користи код Руса и Белоруса: рус. лишиться ума (рассудка), потерять рассудок; бел. стращіџь розум, али и код других народа). Сликовито се губитак памети описује у изразу: врана је некоме попила мозак. Мозак се овде замишља као течност, за разлику од белоруског дијалекатског израза: розум свінні з'елі, где је разум тврда супстанца, нешто што се једе.

Много чешће се безумље описује као стање када недостаје, фали разум, као такозвана „непотпуност”, или „непуноћа”: срп. није читав; бел. дијал. як не узвесь (досл. „као да није читав”) 'чудан, ненормалан'. За опис „непотпуности” језик проналази веома сликовите начине: срп. нису некоме све козе (овие) на броју, рус. не все дома у кого-л., бел. не усе дома у каго (досл. „нису сви код куће код кога”), укр. не всі дома - половина поїхали (досл. „нису сви код куће, пола њих је отишло”). Ови изрази указују на то да постоји норма као „пуноћа" и ред, кад је све на месту и на броју у сеоском домаћинству (српски пример) или код куће (источнословенски примери), док je „непотпуност” нешто што одскаче од норме. У делу израза је овде присутан и мотив кретања, односно одласка из места где неко треба да се налази, у чему се уочава директна паралела са „одласком”, односно губљењем разума.

У источнословенским дијалектима такође постоје изрази повезани са бројевима, а најчешће са бројем сто који се доживљава као „округли” и „потпун" број. О ненормалном човеку се каже: бел. дијал. дзевяноста дзевяиь на фроние і адзін у (на) рамонце у каго (досл. „деведесет девет на фронту, док је један на ремонту"); рус. дијал. девяносто девять не хватает до сотни (досл. ,фали деведесет девет до сто”). 
Изузетно су продуктивни изрази где се „непотпуност” разума сликовито представља као непотпуна конструкција у глави, када фали шраф, ексер, нитна, даска итд., или маст за подмазивање тог механизма. Такви фразеологизми се срећу у различитим језицима: срп. фали некоме даска у глави; нема све (четврте, треће) даске у глави; немати све шарафе у глави; шп. le falta ип tornillo („фали шраф”), рус. винтиков (клепок) не хватает (недостает) в голове у кого; рус. заклёпки не хватает; бел. клёпкі (клёпак) не хапае (не стае) у галаве у каго; бел. пятай клёпкі бракуе; бел. трэияй бэлькі нестае; бел. без пятай дошчачкі; не уссе дошчачкі ў парадку; бел. нар. алею у галаве мала („фали нитна, дрикер, (пета) даска, маст”); нем. nicht alle Tassen im Schrank haben („фале шољице у орману”; такође у немачком има примера када фали нешто у коферу, компјутеру, фиоци, тј. најчешће у затвореном предмету коцкастог облика што представља имплицитно поређење са главом).

Као својеврстан антонимијски модел, издвајају се изрази који описују луду или хировиту особу као особу с нечим сувишним. Најчешће су то инсекти, што је повезано са старим народним веровањима да ђаво у облику инсеката улази у главу човека и изазива психичке болести (Гура 1997: 441-442): срп. има бубе у глави; бел. з мухамі у носе (досл. „са мувама у носу”); рус. с тараканами (досл. „са бубашвабама”); нем. Grillen im Kopf haben (досл. „имати цврчке у глави”).

3.2. Безумље као кретање, померање, губљење ослонца.

Низ лексема и фразеологизама одражава представу о здрављу човека као нечему стабилном. Разум се пореди са површином земље, тлом на којем чврсто стоји човек, што представља његов ослонац, док скретање, померање описује одступање од норме: срп. сићи с ума, скренути (с ума); слични изрази се користе нпр. у руском и белоруском: рус. сходить/сойти с ума, спятить, тронуться (умом, рассудком / в уме, в рассудке), бел. з'ехаць з глузду, крануцица з розуму, сыходзіц̧ь з розуму. О таквим изразима В. Мокијенко пише да се ту ради о одласку, скретању с правог пута. Руско свихнуться је раније значило 'скренути', док је израз свести с ума, тј. навести некога да изгуби памет, настао од израза совратить с пути истинного (досл. „одвући с правог пута"), што је значило 'одвући од истине, разумног'.

Такође, у оквиру овог модела уочавамо да се нормално психичко стање, владање собом и самоконтрола доводи у везу са обитавањем у свом унутарњем бићу, зато се ментални поремећаји описују као излазак ван његових граница и губљење стабилности. Према народним веровањима, луд човек не припада себи него ђаволу: срп. нuје сав свој, уп. пољск. Już sam nie swój, połowina dijabłowa.

Према речима М. Турилове која је истраживала историју лексема са значењем безумља, лудила, семантички пренос 'изаћи ван себе - изгубити разум' веома је стар: овај мотивациони модел је из грчког пренесен у старословенски језик, уп. у црквенословенском руске редакције: ис-стуn-ление 'беснило' (Турилова 2010: 8).

Померање, скретање је пут ка лудилу, и овај модел је изузетно продуктиван у савременим језицима, наиме, у жаргону: срп. откачити; жарг. одле- 
пити; скренути. Често се описују горњи делови различитих грађевина као асоцијација са главом: рус. крыша поехала, башню снесло, срываться с тормозов; бел. з рэха з'ехаў, сыходзіць з катушак („помера се кров, кула, не ради кочница”); нем. einen Dachschaden haben (досл. „кров му је поремећен”), шп. está mal de la azotea (досл. „код њега (ње) је лоше са терасом на горњем спрату").

Мотив „одласка” разума из главе је имплицитно присутан и у ономатопејским речима које описују високи звук као асоцијацију са брзим одласком: срп. фијук, фијукнути; рус. и бел. ку-ку 'ненормалан'.

3.3. Безумље као оштећеност, одсуство целовитости услед ударца, пада, пуцања итд.

Здравље се од давнина повезује са целовитошћу: уп. ис-иел-ити, ис-иелитељ. Ментални простор једне особе у норми мора да буде читав и целовит. Ментални поремећаји се често тумаче као последица пада, ударца или пуцања, и тај модел је продуктиван како у лексици, тако и у фразеологији: ударен мокром крпом / чарапом (по глави); жарг. ошинут; уп. рус. вышибить ум, ум (мозги) отшибло; бел. як (нібы) пыльным мешком (мехам) удараны (nрыбіты) (,ударен по глави, прашњавим џаком” итд.). Крајње напето психичко стање човека се описује као пуцање, и то често предмета округлог облика као асоцијација са главом: пући као сијалица (тиква, лубеница, балон); пукао му је филм.

У целом низу израза различитих језика се користи мотив пада одозго, међутим, овде треба да разликујемо два смисла, 'наиван' и 'луд'. Са једне стране, срп. нисам пао с крушке значи 'нисам наиван'; уп. шп. caer del quindo (досл. „пасти с вишње”) 'бити наиван'. Са друге стране, код Руса и Белоруса изрази са дословним значењем „пасти са храста” описују неразумног човека, неадекватно понашање: рус. с дуба рухнуть, бел. дијал. з дуба ляснуў 'сићи с ума, направити глупост'.

Поређење различитих значења у оквиру наизглед сличног модела има важно методолошко значење јер спречава погрешно тумачење и интерференцију.

4. Примена појма „модел” у анализи фразеолошке грађе омогућава откривање знатног степена сличности израза у различитим језицима, повезивање израза у матерњем и страном језику, што доприноси бољем и потпунијем разумевању, као и бржем усвајању фразеологизама као језичких јединица са веома комплексним значењем. Тако, видели смо да се фразеологизми са значењем безумља у српском језику, као и у многим другим језицима, без обзира на њихову разноликост, групишу око три главна мотива, или сижеа. Анализом модела долазимо до закључака о народном тумачењу света и појава у њему: на пример, ментално здравље се повезује са стабилношћу, комплетношћу, целовитошћу (неоштећеношћу) унутарњег простора, његовом припадношћу самом човеку, што је повезано са најстаријим веровањима и представама о уређењу света.

У настави фразеологије српског језика, у поређењу са другим језицима, од значаја је доследно разграничавање заједничког и специфичног на свим нивоима анализе: од дословног значења до фразеолошких модела и концеп- 
туалних макромодела. Важно је и поређење израза са различитим значењем у оквиру наизглед сличног модела, како би се спречило погрешно разумевање и употреба израза, односно интерференција.

\section{ЛИТЕРАТУРА}

Белић 1951: Александар Белић, Око нашег књижевног језика, Београд.

Гољак 2017: Светлана В. Голяк, Образная концептуализация безумия в русской, белорусской и сербской фразеологии, Славистика, XXI, 89-105.

Гура 1997: Александр В. Гура, Символика животных в славянской культурной традиции, Москва.

Зикова 2014: Ирина В. Зыкова, Музыка как источник фразеологической концептуализации мира (на материале английского и русского языков), Frazeologické štúdie VI. Hudobné motívy vo frazeológii, Bratislava, 362-373.

Караулов 1987: Юрий Н. Караулов, Русский язык и язылковая личность, Москва.

Мокијенко 1989: Валерий М. Мокиенко, Славянская фразеология, Москва.

Мршевић Радовић 2008: Драгана Мршевић-Радовић, Фразеологија и национална култура, Београд.

Сепир 1993: Эдуард Сепир, Избранные труды по языкознанию и культурологии, Москва.

Солодуб 1982: Юрий П. Солодуб, Русские фразеологические обороты со значением качественной оценки лица и структурой глагольного словосочетания как объект сопоставительного структурно-типологического исследования, Системные отношения в лексике и фразеологии (русский язык), Москва, 81-97.

Турилова 2010: Мария В. Турилова, Генетическая и мотиваџионная характеристика лексико-семантического поля „безумие” в русском языке. Автореф. дис. ... канд. фил. наук, Москва.

Светлана В. Голяк

МЕТОДИЧЕСКИЕ АСПЕКТЫ ПРЕПОДАВАНИЯ ФРАЗЕОЛОГИИ СЕРБСКОГО ЯЗЫКА КАК ИНОСТРАННОГО

\section{Резюме}

Результаты современных исследований фразеологии, ориентированных на выявление связей языка и культуры, отражения элементов языковой картины мира в устойчивых единицах, применены в методике преподавания сербской фразеологии как иностранной. Понятие фразеологической модели рассмотрено как в структурно-семантическом плане (метафора), так и в концептуальном макрометафорическом плане (макрометафора как связь культурных кодов). Преподавание фразеологии с анализом фразеологических моделей способствует более глубокому пониманию обучаемыми сложной семантики фразеологизмов, а также связей между различными языками и культурами. В работе это иллюстрируется на материале оборотов со значением 
Светлана В. Гољак

безумия, вербальной коммуникации, а также со значением 'никогда'. Сопоставление сербского материала с примерами из многих других языков позволяет выявить общее и различное в семантике оборотов, обнаружить случаи частичного несовпадения значений в рамках одной модели и тем самым предупредить интерференцию.

Ключевые слова: фразеологизм, сербский язык, методика преподавания, модель. 